\title{
The impact of educators' skills and training on the delivery of music in the learning area Arts and Culture within two districts of the Gauteng province of South Africa
}

\section{Christopher KIopper}

Charles Sturt University, Panorama Avenue, Bathurst NSW 2795, Australia

cklopper@csu.edu.au

This article is the documentation of a sub-research question of a larger empirical study that employed quantitative methods to identify variables that are impacting on the delivery of music in the learning area Arts and Culture in South Africa extrapolated from questionnaires. Analysis of the data revealed that educators lack specialisation in music and have limited training in any of the art forms. Significant relationships were established between the educator and involvement in music activities within and outside of the school environment.

\section{Introduction}

The restructuring of South African education has been part of a larger - and still unfinished post-apartheid process of creating a democratic society. The realisation of the restructuring has been fostered in Curriculum 2005 (C2005) (South Africa 1997a), which is an attempt to align what happens in schools with both the demands of the global workplace as well as the social and political aspirations of the post 1994 South Africa. In the words of Taylor (1997), C2005 aims to:

- develop citizens who are active and creative, inventors and problem solvers, rather than meek and unthinking followers; and

- inculcate an appreciation for diversity in the areas of race, culture and gender (1997: 1).

The arts are well entrenched in C2005 in the form of the learning area Arts and Culture, which is one of the eight compulsory learning areas for all learners from Grades 4-9 (915 years old). As a former Education Specialist in the Johannesburg North District and in the Tshwane South District for the learning area Arts and Culture for the Gauteng Department of Education, I observed daily that Arts and Culture does not feature on the timetables of many schools. Principals appeared not to be interested in this learning area, teachers were uncertain of what or how to teach, with the result that the learners were not taught about the arts in the learning area. During the moderation of the learning area portfolios (a collection and selection of learners' work), it became apparent that there was little substantial evidence of effective teaching and learning. Learners' portfolios were filled with written activities and little if any reference to learning processes in the arts. The majority of portfolios illustrated a few visual art works, scripts for dramas and slight references to performances of drama and dance, but hardly ever a reference to music. The lack of musical experiences in the classroom places the new curriculum strategy at risk. When discussing the situation with the educators, I was often told that 'We don't know 
about music!' or 'We don't have resources to teach music' or 'I never studied Arts and Culture'. It is therefore evident that research was needed to ascertain which variables are impacting on the delivery of music in the learning area Arts and Culture in South Africa (Klopper, 2004).

Policymakers and education leaders are facing challenging issues related to educational governance, finance, policymaking and management (South Africa 1994, 1995a, 1995b, 1995c, 1995d, 1996a, 1996b, 1996c, 1996d, 1997a, 1997b, 2000, 2002a, 2002b). While Director of the Music Action Team Research Cells (MAT cells) for the Pan African Society for Musical Arts Education (PASMAE http://www.pasmae.org) between 2003-2005, I coordinated the findings and discussions of musical instruction and activities of the MAT cell leaders of their respective regions in Africa, including South Africa. At the $3^{\text {rd }}$ Biennial Conference of PASMAE held in Kenya in 2003, four main issues were evident in all the countries' research (Klopper, 2003: 3 ; 2005) in relation to education reform and transformation. Not all are unique to South Africa but rather generic throughout the African continent. These are:

- Curriculum issues with regard to changes in policy.

- Lack of facilities and resources.

- Skills, training and methodology of practising art educators in schools and higher education institutions.

- The societal role of Arts Education.

These findings of the MAT cells and issues highlighted here are supported further by the documentation of factors that influence the implementation of policy and therefore curriculum development (Victoria, 1998: 19):

- Current government education policy.

- Educational philosophy and tradition of the school.

- Expectations, support and facilities of the local community.

- Expertise, interests and values of teachers.

- Prior experiences and expectations of the students.

- Physical resources, facilities and time available for the arts.

The situation in South African schools offering the learning area Arts and Culture is by no means exempt from these factors raised in Africa and internationally. Professor Kader Asmal, former Minister of Education, convened the Music in Schools Symposium (May 2000) as a result of his experiences while travelling across the country, when he realised that the enormous music potential was not allowed to flourish. Speaking at the Music in Schools Symposium held on 19-20 May 2000 he stated:

Given the declining budgets and prominence afforded to learning areas like mathematics, science and technology, there is a danger that music education will be relegated to the margins of the teaching and learning process. However, the value of music in the general learning experience of learners cannot, and dare not, be underestimated (Asmal, 2000).

Asmal's statement describes the situation in many schools. In general the value of music is never disputed, but the apparent lack of financial or human resources for this component 
of the learning area is of concern. Furthermore, the concerns raised by Asmal (2000) are echoed by the findings of the MAT cells in Africa. Such findings and documentation at grassroot levels by practicing educators, principals and learners exposes the situation in schools.

\section{Overview of the learning area Arts and Culture}

In the intermediate and senior phases of schooling, termed 'Intersen', Grades 4-9 (1016 year olds) of the General Education and Training Band (GET) of the learning area Arts and Culture proposed for C2005 (South Africa 1994: 9) the following sub-fields are included: music, dance, drama, visual arts, media, communication, technology, design, literature and sport. The inclusion of these sub-fields is seen as an affirmation of the integrity and importance of the various art forms found in South Africa.

The legitimisation of the arts within C2005 in South Africa is a double-edged sword. Although the arts are represented in the curriculum in the form of the learning area Arts and Culture (South Africa 1997b: AC1-AC21), the irony is that this documentation does not secure a place for any one of the art forms. The very nature of the outcomes stated in the learning area allows for them to be attained through any of the art forms. Depending on the area of expertise or interest of the educator, financial resources for physical resources, or the societal role of arts in the school, these outcomes could be attained through the medium of music, the visual arts, drama or dance. For the survival of the individual art forms under this new dispensation, a concerted effort must be made to establish how they can possibly survive and coexist productively.

\section{Research problem}

Hauptfleisch (1997: 21) proposed 'the systems approach [as] an optimal approach to addressing problems'. Ossenbruggen (1994: 1) defines a system as an organised, integrated unit that serves a common purpose. Hauptfleisch (1997: 23) adopted this definition and suggested that a system can be defined as 'a set of objects with specific attributes, related to one another and to their environment, that work together for the overall objective of the whole'. Churchman (1968) identified three kinds of objects in a system: inputs, processes and outputs. He defined the three identified objects as follows:

- Inputs provide a system with its operating necessities (resources) such as energy, human beings and information;

- Processes transform inputs into outputs;

- Outputs are the purpose for which a system exists (1968: 62-3).

Churchman (1968: 39) noted that a component for increasing resources may be the most important one in many systems. Hauptfleisch's challenge to the music community was to embrace the situation as a system to achieve its full potential. It is evident from the research outlined that such an approach has not happened and that the outlook for music education is not a favourable one. Taking heed of Churchman's (1968: 39) point 'that a component for increasing resources may be the most important one in many systems', a closer examination and investigation of the inputs and not the processes or outputs is necessary. The recommendations made by Rijsdijk (2003) and Herbst et al. (2005) suggest 
that attention be focused on operating necessities. Furthermore, a report entitled 'Evaluation of C2005 Implementation in Gauteng Province - Challenges, Constraints, Innovations and Successes of 1998 to 2001' revealed the study findings of Khulisa Management Services (2002), which indicated the variables outside the classroom that impact on the implementation of outcomes-based education/Curriculum 2005. That research culminated in the presentation of findings, which were broadly classified into four indicators. In a similar study undertaken by Harvey Research, Canada in 1988, the factors affecting curriculum implementation were documented. The report supports the earlier research that I documented which identified some factors appearing to influence the implementation of policy and therefore the curriculum from a theoretical perspective and not just in terms of practical needs (Klopper, 2003). Vakalisa (2000) cites obstacles in implementing C2005, supported by the sentiments of Breidlid (2003) and Friedman (2003) regarding the difficulty of understanding the new concepts in South African education reform.

Since processes are defined as transforming inputs into outputs, and that the output is the reason for a system to exist, if the inputs are not beneficial to the system the system cannot function effectively or even at all. To identify the variables impacting on the delivery of Music in the learning area Arts and Culture in South Africa an investigation of empirical data was undertaken (Klopper, 2004).

\section{Methodology}

Self-administered questionnaires were selected as being the most cost effective and suitable in terms of covering a great number of schools within a large area in a limited period of time. The self-administered questionnaire was confined to the Tshwane South district. The aim of the questionnaire was to investigate the learning area Arts and Culture with specific reference to music in order to identify and quantify variables impacting on the delivery of Music in the learning area Arts and Culture. To be able to accomplish this investigation, the content of the questionnaires centred on the following three groups of respondents:

- The educators who implement Music in the learning area Arts and Culture.

- The learners in the Senior Phase (Grades 7-9), who experience the learning area Arts and Culture as one of the compulsory learning areas in this phase.

- The principals who manage the curriculum in their schools.

The following three objectives were set for each of the questionnaires:

- Do the educator's skills and training impact on delivery?

- Do facilities and resources impact on delivery?

- Does the societal role of the arts impact on delivery?

For the purpose of this article the analysis and findings focuses only on the impact of the educator's skills and training on music in the learning area Arts and Culture in South Africa.

\section{Sample profile}

Gauteng is considered to be the most industrialised province and the economic hub of South Africa, yet it is still faced with the challenges of unemployment, crime, illiteracy, disease, homelessness and lack of basic services such as water and electricity 
(http://www.gauteng.net/home/fact.asp). The Gauteng province is the smallest of South Africa's nine provinces, measuring 18810 square kilometres. The population of Gauteng is the second largest of all provinces, totalling about 8.8 million. Its three main cities are Johannesburg, Soweto and Tshwane. The Gauteng Department of Education is divided into 12 smaller districts. Each district is comprised of no fewer than 150 schools. The two districts selected and involved with the pilot study were Johannesburg North and Tshwane South. This allowed for access to 375 schools. The main study was executed in the Tshwane South district, which amounted to 228 schools being involved. District Tshwane South is one of the 12 districts in Gauteng and is positioned primarily in Pretoria and the surrounding areas including Mamelodi, Eersterus, Atteridgeville, Silverton, Centurion and Laudium. The sampling method employed for the educators was one of probability sampling.

\section{Educators}

All 228 schools covering the senior phase (Grades 7-9) (12-15 years old) were invited to attend afternoon moderation sessions over a period of one week in November 2003. A total of 184 educators finally responded to the questionnaire, covering 163 schools of the total possible number of 228 . This is a $71 \%$ participant return of the possible sample targeted. This is regarded as a very high return rate for questionnaires, but cognisance must be taken of the fact that it was a self-administered questionnaire and so there was little regard for non-response due to mail delivery problems or participant apathy.

\section{Presentation of descriptive analysis}

The questionnaire for educators of Arts and Culture consisted of 34 questions under four main sections: background information, school teaching experience, experience of the arts and level implementation. What follows is a presentation and commentary of the questions that were designed to elicit information pertaining to the extent to which educator's skills and training are impacting on the delivery of music in the learning area Arts and Culture.

\section{Background information}

- What is the highest educational qualification you have obtained?

\begin{tabular}{|l|c|c|c|}
\hline $\mathrm{N}=184$ & & Frequency & $\%$ \\
\hline Degree & 1 & 78 & 42.39 \\
\hline Diploma & 2 & 97 & 52.72 \\
\hline Certificate & 3 & 9 & 4.89 \\
\hline
\end{tabular}


The majority of respondents indicated that their highest educational qualification obtained was a diploma. The next largest group had obtained a degree. Only a small percentage (just less than $5 \%$ ) were in possession only of a certificate. The next question inquired about the year of qualification. Three categories were offered: prior to 1980, between 1980 and 1990 and post-1994. The three categories were selected as significant time periods. Prior to 1980 referred to a time in South Africa of political stability. Between 1980 and 1990 the political instability was felt as marginalised groups began to voice their opinions and be heard. Post-1990 appeared to be the start of dynamic change in South Africa and, as previously outlined, the reformation in education began. The date of qualification has also been used as an indication of the age of the educator. The approximate age of the educator might also have an impact on the delivery of the learning area in terms of willingness to adapt to the changes that educators face.

- In what field (direction) did you specialise?

\begin{tabular}{|l|c|c|c|}
\hline $\mathrm{N}=184$ & 1 & Frequency & $\%$ \\
\hline $\begin{array}{c}\text { Humanities (Arts, sociology, } \\
\text { philosophy, theology) }\end{array}$ & 2 & 35 & 102 \\
\hline $\begin{array}{c}\text { Natural sciences (Agricultural, } \\
\text { biological, physical) }\end{array}$ & 3 & 6 & 3.26 \\
\hline $\begin{array}{c}\text { Mathematical sciences (Engineering, } \\
\text { statistics) }\end{array}$ & 4 & 65 & 35.33 \\
\hline Languages & 5 & 17 & 9.24 \\
\hline $\begin{array}{c}\text { Commercial (Economics, typing, } \\
\text { business economics, accounting) }\end{array}$ & 17 & \\
\hline
\end{tabular}

The respondents had to indicate the field (direction) in which they specialised as an indication of how many of the practising educators are teaching in the field of their specialisation. Only 55\% (data from accompanying tables are rounded) of the sample indicated a specialised field in the Humanities. The category of Humanities encompassed the arts, sociology, philosophy and theology. The next substantial category of response was the field of Languages, followed by the Natural Sciences, Commercial and Mathematical Sciences. The indication of Humanities was not specific enough to enable any further suppositions without enquiring as to what training the respondents had received in the Arts and the duration of the training, which would reveal what level of specialisation had been obtained in the chosen field of the arts. 
- If you have had training in any of the following, please indicate the duration of such training. (less than 1 year would be short courses of weeks or months duration).

\begin{tabular}{|c|c|c|c|c|c|c|c|c|}
\hline & 0 & $\%$ & $\begin{array}{l}\text { Less } \\
\text { than } \\
1 \text { year }\end{array}$ & $\%$ & 1 year & $\%$ & $\begin{array}{c}2 \text { years } \\
\text { or } \\
\text { more }\end{array}$ & $\%$ \\
\hline Arts (Visual) & 113 & 61.41 & 28 & 15.22 & 9 & 4.89 & 34 & 18.48 \\
\hline Crafts & 145 & 78.80 & 16 & 8.70 & 1 & 054 & 22 & 11.96 \\
\hline Music & 132 & 71.74 & 19 & 10.33 & 5 & 2.72 & 28 & 15.22 \\
\hline Drama & 136 & 73.91 & 23 & 12.50 & 7 & 3.80 & 18 & 9.78 \\
\hline Dance & 156 & 84.78 & 15 & 8.15 & 2 & 1.09 & 11 & 5.98 \\
\hline Other (specify) & 181 & 98.37 & 1 & .54 & 1 & .54 & 1 & .54 \\
\hline
\end{tabular}

The above tabulation illustrates the high frequency of short courses of weeks or months in duration in the differing fields of the arts provided as options. A closer examination revealed that, of the respondents who indicated training in music, only $15 \%$ had undergone training of 2 or more years. This would translate into their having obtained their qualification with a specialisation in music. No distinction was made as to whether this qualification was in Class Music, Performance Music or Music Education. Only the Arts (visual) and Crafts categories saw similar responses. The strands of Drama, Dance and Other received very small, negligible responses.

\section{School teaching experience}

- State your current position at your school.

\begin{tabular}{|l|c|c|c|}
\hline $\mathrm{N}=184$ & & Frequency & $\%$ \\
\hline Permanent state post & 1 & 121 & 65.76 \\
\hline Temporary state post & 2 & 29 & 15.76 \\
\hline School governing body post & 3 & 34 & 18.48 \\
\hline
\end{tabular}

The state provides teaching posts per school based on a ratio of learner to educator. If a school wishes to employ further educators, they do so at their own cost and such posts are called school governing body posts. The creation of such posts places extreme financial pressure on a school. Indications are that $65 \%$ of the educators have permanent state posts. A further $15 \%$ have temporary state posts; $81 \%$ were being paid by the state and 
only $18 \%$ were receiving remuneration from school governing bodies. A commitment from the state to supplying educators for the necessary teaching and learning in schools is implied.

- What grade/s do you teach at present?

\begin{tabular}{|l|c|c|}
\hline $\mathrm{N}=184$ & Frequency & $\%$ \\
\hline Grade 4 & 37 & 20.11 \\
\hline Grade 5 & 50 & 27.17 \\
\hline Grade 6 & 64 & 34.78 \\
\hline Grade 7 & 112 & 60.87 \\
\hline Grade 8 & 55 & 29.89 \\
\hline Grade 9 & 74 & 40.22 \\
\hline
\end{tabular}

It is still customary in the primary school (Grades 1-7) (5-13 years old) for educators to be generalists. The educator is required to teach all learning areas regardless of specialisation. If the school is able to afford a specialist for the learning area Arts and Culture, the educator would often find himself or herself teaching across all the grades, and therefore when this question was asked the respondents were able to opt for grades, which are not covered in the senior phase. Similarly, educators teaching in secondary schools (Grades 8-12) also find themselves having to teach more than one grade and thus in Grade 8 and Grade 9 many educators were represented in these categories. A high percentage of the respondents $(60 \%)$ indicated teaching at Grade 7 level. However, the bulk of the respondents are teaching in the senior phase (Grade 7-9).

- What phase/s are you currently teaching?

\begin{tabular}{|l|r|r|c|}
\hline & & Frequency & $\%$ \\
\hline Early Childhood Development Phase (Grade R to Grade 3) & 1 & 8 & 4.35 \\
\hline Intermediate Phase (Grade 4 to Grade 6) & 2 & 65 & 35.33 \\
\hline Senior Phase (Grade 7 to Grade 9) & 3 & 168 & 91.30 \\
\hline Further Education andTraining Phase (Grade 10 to Grade 12) & 4 & 27 & 14.67 \\
\hline
\end{tabular}

A total of $91 \%$ of respondents designate their phase that they are currently teaching as being the Senior Phase. This supports this research in terms of validity and reliability, as the respondents' responses are based on the phase examined in this study. 
- Were you trained to teach in this phase?

\begin{tabular}{|l|c|c|c|}
\hline $\mathrm{N}=183$ & & Frequency & $\%$ \\
\hline Yes & 1 & 138 & 75.41 \\
\hline No & 2 & 45 & 24.59 \\
\hline
\end{tabular}

Although prior questions revealed that many of the practising Arts and Culture educators participating in this research had not received formal training in one or more of the arts disciplines, $75 \%$ were trained as generalists to teach in the phase in which they are currently teaching. However, having received the appropriate didactic training for a phase does not secure the appropriate training for the learning area the educator ultimately teaches.

- How many years teaching experience do you have teaching your art form/s?

\begin{tabular}{|l|c|c|c|}
\hline $\mathrm{N}=181$ & & Frequency & $\%$ \\
\hline Less than 10 years & 1 & 119 & 65.75 \\
\hline Between 10 and twenty years & 2 & 33 & 18.23 \\
\hline More than twenty years & 3 & 29 & 16.02 \\
\hline
\end{tabular}

It appears that for the large majority of practicing Arts and Culture educators, their level of experience measured in terms of length of service is less than 10 years. This is not perceived as negative but rather positive, as these educators less experienced in terms of years have had the good fortune of having qualified during the dynamic period of reform in education. This is not to suggest that the educators of the other two categories would not have been able to embrace change, but the younger educators have been part of the change process.

- Are you involved in any arts or cultural activities extramurally?

\begin{tabular}{|l|c|c|c|}
\hline $\mathrm{N}=183$ & & Frequency & $\%$ \\
\hline Yes & 1 & 125 & 68.31 \\
\hline No & 2 & 58 & 31.69 \\
\hline
\end{tabular}

The term extramural refers to activities that take place under the auspices of the school after the recognised school day. Not only do such activities offer learners many opportunities, but educators are also able to interact with learners away from the classroom environment in offering a holistic approach to education. For many educators such activities are a given requirement of the school and no remuneration is offered. However, the trend appears to be changing and more affluent schools tend to, on their own initiative, offer monetary reward for educators who are involved extramurally. Of the respondents, $68.31 \%$ specified 
being involved in extramural activities. The extramural activities noted by the respondents included: school productions, traditional dancing groups, music performing groups (choirs, bands, ensembles), cultural groups, drama groups, debating and public speaking, visual arts groups, photography; and Department of Education organised competitions and events.

- Are you involved in any Arts and Culture activities outside of the school?

\begin{tabular}{|l|c|c|c|}
\hline $\mathrm{N}=180$ & & Frequency & $\%$ \\
\hline Yes & 1 & 73 & 40.56 \\
\hline No & 2 & 107 & 59.44 \\
\hline
\end{tabular}

The response suggests the level of commitment to the 'arts' from the practising educators and also the level of expertise and willingness of the educators to be seen as practicing 'artists'. Only 40\% specify that they are involved with Arts and Culture activities outside of the school environment, and 59\% specify that they are not involved in such activities. The following activities were indicated by $40 \%$ as activities outside of the school environment: choreography, author of resource books, drama groups, instrument lessons, choirs, church musician, band member, art classes, visual art competitions, photography, dancing and pottery. Of these categories only three were of any significance in number, namely choreography, drama groups and choirs.

\section{Experience of the arts}

- Do you have a personal interest in any of the following?

\begin{tabular}{|l|c|c|c|}
\hline & & Frequency & $\%$ \\
\hline Storytelling & 1 & 89 & 48.37 \\
\hline Painting & 2 & 94 & 51.09 \\
\hline Sculpture & 3 & 43 & 23.37 \\
\hline Pottery & 4 & 51 & 27.72 \\
\hline Dance & 5 & 99 & 53.80 \\
\hline Drama & 6 & 97 & 52.72 \\
\hline Performing music & 7 & 81 & 44.02 \\
\hline Listening to music & 8 & 113 & 61.41 \\
\hline Going to the theatre & 9 & 108 & 58.70 \\
\hline Any other cultural activities (specify): & & 5 & 2.71 \\
\hline
\end{tabular}


By offering differing categories, the respondents' options were channelled. The question only required the respondent to indicate if they had a personal interest in the categories on offer. Here the $61 \%$, the highest response, draws attention to the fact that they enjoy listening to music and $44 \%$ indicate that they enjoy performing music. So in this research sample many educators indicated a personal interest in the 'Arts' and specifically music (by the majority), but do not commit themselves to actively participating in Arts and Culture activities outside of the school environment.

- Do you think Arts and Culture education is important for young learners?

\begin{tabular}{|l|c|c|c|}
\hline $\mathrm{N}=184$ & & Frequency & $\%$ \\
\hline Yes & 1 & 183 & 99.46 \\
\hline No & 2 & 1 & .54 \\
\hline
\end{tabular}

Almost $100 \%$ replied that they viewed the learning area Arts and Culture as being important for young learners. Support for this was indicated, with the following reasons provided: offers holistic education, creates an interest in cultural diversity, develops skills, teaches discipline, nurtures an appreciation of the Arts, develops creativity and aids social development. Such support establishes the importance of the learning area, but it does not secure a commitment of those with the expertise and interest to the learning area.

- Which one of the art forms do you prefer working in?

\begin{tabular}{|l|c|c|c|}
\hline $\mathrm{N}=144$ & & Frequency & $\%$ \\
\hline Visual arts & 1 & 73 & 50.69 \\
\hline Music & 2 & 30 & 20.83 \\
\hline Dance & 3 & 14 & 9.72 \\
\hline Drama & 4 & 27 & 18.75 \\
\hline
\end{tabular}

The natural bias of the educator is a given in the approach to the learning area Arts and Culture by virtue of the fact there is little chance of specialising in all four art forms (visual art, music, dance and drama); specialisation would have occurred in only one of the four, if at all. A preference to working in Visual arts was indicated by $50 \%$ of educators. The remaining $50 \%$ is divided amongst the three other strands, of which Music makes up 20\%, closely followed by Drama and finally Dance.

\section{Level of implementation}

- Using the provided scale below, choose the level of implementation, which you regard as best describing your school and Arts and Culture. 


\begin{tabular}{|l|c|c|c|}
\hline $\mathrm{N}=184$ & & Frequency & $\%$ \\
\hline Arts and Culture is not being delivered at all & 1 & 5 & 2.72 \\
\hline $\begin{array}{c}\text { Arts and Culture features on the timetable but is hardly } \\
\text { taking place }\end{array}$ & 2 & 10 & 5.43 \\
\hline $\begin{array}{c}\text { Arts and Culture sees its rightful place in the school but } \\
\text { not all four strands are being delivered effectively }\end{array}$ & 3 & 107 & 58.15 \\
\hline $\begin{array}{c}\text { Arts and Culture sees its rightful place in the school } \\
\text { with all four strands being delivered effectively }\end{array}$ & 4 & 62 & 33.70 \\
\hline
\end{tabular}

The four-level rating used for assessment in the school system at present prompted the use of four levels for this question. Educators are familiar with rating responses on a four-level system. This four-level system also encouraged respondents to offer as accurate a response as possible, because if they have only four levels to choose from, they will not be able to indicate the 'middle of the road' response or error of central tendency (Oppenheim, 1992: 233). A total of $58 \%$ of the educators regard themselves as achieving a level rating of three. This implies that Arts and Culture sees its rightful place in the school, but not all four strands are being delivered effectively.

\section{Summary of descriptive analysis findings}

The analysis of the data sourced from the educators illustrated that the learning area is viewed as important. Albeit all the educators possess a qualification, there is a lack of specialisation in the arts among the educators. This impact is further influenced by the limited knowledge of the educator, which is possibly linked to the limited training in any of the arts that the educators received. Those who have an arts qualification alluded to the fact that they have a natural bias to the art form in which they have some training. For the majority this training was not in music. The educators also indicated that they have little involvement in the extramural activities of the school and also outside of the school environment.

\section{Presentation of inferential analysis findings}

The following null hypotheses are explored through presenting the chi-squared results which are then narrated to provide credibility to the hypothesis.

- There is no inference between the type of qualification obtained by an educator and the year in which the educator qualified 


\begin{tabular}{|c|c|c|c|c|}
\hline \multirow{2}{*}{$\begin{array}{l}\text { Statement of null hypothesis } \\
\text { Frequency } \\
\text { Per cent } \\
\text { Row Pct } \\
\text { Col Pct }\end{array}$} & \multicolumn{4}{|c|}{$\begin{array}{c}\text { There is no inference between the type of qualification } \\
\text { obtained by an educator and the year in which the } \\
\text { educator qualified }\end{array}$} \\
\hline & $\begin{array}{c}\text { Before } 1980 \\
1\end{array}$ & $\begin{array}{l}1980-1990 \\
2\end{array}$ & $\begin{array}{l}\text { Post } 1990 \\
3\end{array}$ & total \\
\hline $\begin{array}{l}1 \\
\text { Degree }\end{array}$ & $\begin{array}{r}11 \\
5.98 \\
14.10 \\
23.40\end{array}$ & $\begin{array}{l}23 \\
12.50 \\
29.49 \\
37.70\end{array}$ & $\begin{array}{l}44 \\
23.91 \\
56.41 \\
57.89\end{array}$ & $\begin{array}{l}78 \\
42.39\end{array}$ \\
\hline $\begin{array}{l}2 \\
\text { Diploma }\end{array}$ & $\begin{array}{l}30 \\
16.30 \\
30.93 \\
63.83\end{array}$ & $\begin{array}{l}35 \\
19.02 \\
36.08 \\
57.38\end{array}$ & $\begin{array}{l}32 \\
17.39 \\
32.99 \\
42.11\end{array}$ & $\begin{array}{l}97 \\
52.72\end{array}$ \\
\hline $\begin{array}{l}3 \\
\text { Certificate }\end{array}$ & $\begin{array}{l}6 \\
3.26 \\
66.67 \\
12.77\end{array}$ & \begin{tabular}{r}
\multicolumn{1}{l}{3} \\
1.63 \\
33.33 \\
4.92
\end{tabular} & $\begin{array}{l}0 \\
0.00 \\
0.00 \\
0.00\end{array}$ & $\begin{array}{l}9 \\
4.89\end{array}$ \\
\hline Total & $\begin{array}{l}47 \\
25.54\end{array}$ & $\begin{array}{l}61 \\
33.15\end{array}$ & $\begin{array}{l}76 \\
41.30\end{array}$ & $\begin{array}{l}184 \\
100.00\end{array}$ \\
\hline Statistic & DF & Value & Prob & \\
\hline $\begin{array}{l}\text { Chi-Square } \\
\text { Likelihood Ratio Chi-Square } \\
\text { Mantel-Haenszel Chi-Square } \\
\text { Phi Coefficient } \\
\text { Contingency Coefficient } \\
\text { Cramer's V } \\
\text { WARNING: } 33 \% \text { of the cells } \\
\text { Effective Sample Size }=184\end{array}$ & ve expected co & $\begin{array}{c}21.2739 \\
23.5351 \\
19.9967 \\
0.3400 \\
0.3219 \\
0.2404 \\
\text { nts less than } 5\end{array}$ & $\begin{array}{l}0.0003 \\
<.0001 \\
<.0001\end{array}$ & \\
\hline
\end{tabular}

The observed $\chi^{2}$-value of 21.2739 is statistically significant at the 0.0003 level. Therefore the null hypothesis must be rejected and the hypothesis of inference between the type of qualification and the year in which the qualification was obtained must be accepted. There is a significant association between the type of qualification and the year in which it was obtained. The warning placed on this $\chi^{2}$ test is due to the fact that certain cells have a frequency of less than five. To fine-tune this test further these cells could be disregarded. However, this would not add value to this study, as it is significant to note that the number of certificate qualifications offered by tertiary institutions has diminished over a period of time, suggesting a significant increase to the level of qualification now accessible to aspirant 
educators. The trend is confirmed by the linear increase of degree qualifications obtained over the time periods observed. This trend is observed in the increase of $14 \%$ to $56 \%$ of degrees obtained from before 1980 to those obtained after 1990. The positive upward trend implies that the level of qualifications of educators who qualified after 1990 is higher than the level before 1980. The simultaneous maintenance of diploma acquisition has continued without any significant change. However, the positive progress of higher qualifications obtained by educators does not account for the majority of $58 \%$ of educators who qualified prior to 1990. This majority is therefore practising as educators with limited qualifications as opposed to the $41 \%$ of educators who were able to obtain a higher qualification. It must be noted that not only the number of years that teachers study influences the implementation of music, but also the quality of teacher education. The quality of teacher education was outside the remit of this study.

- There is no inference between the category of post and the length of teaching experience

\begin{tabular}{|c|c|c|c|c|}
\hline \multirow{2}{*}{$\begin{array}{l}\text { Statement of null } \\
\text { hypothesis } \\
\text { Frequency } \\
\text { Percent } \\
\text { Row Pct } \\
\text { Col Pct }\end{array}$} & \multicolumn{4}{|c|}{$\begin{array}{l}\text { There is no inference between the category of post against the } \\
\text { length of teaching experience }\end{array}$} \\
\hline & $\begin{array}{l}\text { Less than } 10 \text { years } \\
1\end{array}$ & $\begin{array}{l}10-20 \text { years } \\
2\end{array}$ & $\begin{array}{l}\text { Greater than } 20 \text { years } \\
3\end{array}$ & total \\
\hline $\begin{array}{l}1 \\
\text { Permanent state post }\end{array}$ & $\begin{array}{l}69 \\
38.12 \\
57.98 \\
57.98\end{array}$ & $\begin{array}{l}24 \\
13.26 \\
20.17 \\
72.73\end{array}$ & $\begin{array}{l}26 \\
14.36 \\
21.85 \\
89.66\end{array}$ & $\begin{array}{c}119 \\
65.75\end{array}$ \\
\hline $\begin{array}{l}2 \\
\text { Temporary state post }\end{array}$ & $\begin{array}{l}22 \\
12.15 \\
78.57 \\
18.49\end{array}$ & $\begin{array}{r}3 \\
1.66 \\
10.71 \\
9.09\end{array}$ & $\begin{array}{c}3 \\
1.66 \\
10.71 \\
10.34\end{array}$ & $\begin{array}{l}28 \\
15.47\end{array}$ \\
\hline $\begin{array}{l}3 \\
\text { School governing post }\end{array}$ & $\begin{array}{l}28 \\
15.47 \\
82.35 \\
23.53\end{array}$ & $\begin{array}{c}6 \\
3.31 \\
17.65 \\
18.18\end{array}$ & $\begin{array}{l}0 \\
0.00 \\
0.00 \\
0.00\end{array}$ & $\begin{array}{l}34 \\
18.78\end{array}$ \\
\hline Total & $\begin{array}{l}119 \\
65.75\end{array}$ & $\begin{array}{l}33 \\
18.23\end{array}$ & $\begin{array}{l}29 \\
16.02\end{array}$ & $\begin{array}{l}181 \\
100.00\end{array}$ \\
\hline \multicolumn{2}{|l|}{ Statistic } & \multicolumn{3}{|c|}{ Prob } \\
\hline Chi-Square & 4 & 12.7979 & 0.0123 & \\
\hline $\begin{array}{l}\text { Likelihood Ratio } \\
\text { Chi-Square }\end{array}$ & 4 & 18.0926 & 0.0012 & \\
\hline $\begin{array}{l}\text { Mantel-Haenszel } \\
\text { Chi-Square }\end{array}$ & 1 & 11.4606 & 0.0007 & \\
\hline Phi Coefficient & & 0.2659 & & \\
\hline Contingency Coefficient & & 0.2570 & & \\
\hline $\begin{array}{l}\text { Cramer's V } \\
\text { Effective Sample Size = } \\
\text { Frequency Missing = }\end{array}$ & & 0.1808 & & \\
\hline
\end{tabular}


The observed $\chi^{2}$ value of 12.7979 is statistically significant at the 0.0123 level. Therefore there is a significant association between the categories of post against the length of teaching experience. Such inference is confirmed in the observance of $65 \%$ educators having less than 10 years teaching experience, $57 \%$ of whom have permanent state posts. The remaining $42 \%$ are divided between temporary state posts and school governing body posts, where the school governing body posts make up $23 \%$. The significant decrease in frequency of permanent state posts according to length of teaching experience is supported by the fact the learning area Arts and Culture is relatively new and a bulk of educators (41\%) qualified after 1990, which correlates with a teaching experience of less than 10 years. It is noted that $65 \%$ of the practising educators benefit from a permanent state post. However, this does not secure a place for Arts and Culture educators, as the state does not allocate posts to learning areas specifically, but rather to schools to be utilised accordingly. This can result in an excess of post appointments to one particular learning area and a shortage in other learning areas.

- No significant relationship exists between a race group and involvement in activities outside of the school environment

\begin{tabular}{|c|c|c|c|c|c|}
\hline $\begin{array}{l}\text { Statement of null } \\
\text { hypothesis }\end{array}$ & \multicolumn{5}{|c|}{$\begin{array}{l}\text { No significant relationship exists between a race group } \\
\text { and involvement in activities outside of the school } \\
\text { environment }\end{array}$} \\
\hline \multicolumn{6}{|l|}{$\begin{array}{l}\text { Frequency } \\
\text { Percent }\end{array}$} \\
\hline $\begin{array}{l}\text { Row Pct } \\
\text { Col Pct } \\
1 \\
\text { Yes }\end{array}$ & $\begin{array}{l}\text { White } \\
1 \\
38 \\
21.23 \\
52.05 \\
52.78\end{array}$ & $\begin{array}{l}\text { Black } \\
2 \\
28 \\
15.64 \\
38.36 \\
32.18 \\
\end{array}$ & $\begin{array}{l}\text { Coloured } \\
3 \\
3 \\
1.68 \\
4.11 \\
42.86\end{array}$ & $\begin{array}{c}\text { Indian } \\
4 \\
4 \\
2.23 \\
5.48 \\
30.77\end{array}$ & $\begin{array}{l}\text { Total } \\
73 \\
40.78\end{array}$ \\
\hline $\begin{array}{l}2 \\
\text { No }\end{array}$ & $\begin{array}{l}34 \\
18.99 \\
32.08 \\
47.22 \\
\end{array}$ & $\begin{array}{l}59 \\
32.96 \\
55.66 \\
67.82 \\
\end{array}$ & $\begin{array}{r}4 \\
2.23 \\
3.77 \\
57.14 \\
\end{array}$ & $\begin{array}{r}9 \\
5.03 \\
8.49 \\
69.23 \\
\end{array}$ & $\begin{array}{l}106 \\
59.22\end{array}$ \\
\hline Total & $\begin{array}{l}72 \\
40.22\end{array}$ & $\begin{array}{l}87 \\
48.60\end{array}$ & $\begin{array}{l}7 \\
3.91 \\
\end{array}$ & $\begin{array}{l}13 \\
7.26\end{array}$ & $\begin{array}{l}179 \\
100\end{array}$ \\
\hline Statistic & DF & Value & Prob & & \\
\hline Chi-Square & 3 & 7.5054 & 0.0574 & & \\
\hline $\begin{array}{l}\text { Likelihood Ratio } \\
\text { Chi-Square }\end{array}$ & 3 & 7.5130 & 0.0572 & & \\
\hline $\begin{array}{l}\text { Mantel-Haenszel } \\
\text { Chi-Square }\end{array}$ & 1 & 4.1376 & 0.0419 & & \\
\hline Phi Coefficient & & 0.2048 & & & \\
\hline $\begin{array}{l}\text { Contingency } \\
\text { Coefficient }\end{array}$ & & 0.2006 & & & \\
\hline $\begin{array}{l}\text { Cramer's V } \\
\text { WARNING: } 25 \% \\
\text { Effective Sample S } \\
\text { Frequency Missing }\end{array}$ & $\begin{array}{l}\text { he cells } \\
=179 \\
5\end{array}$ & $\begin{array}{l}0.2048 \\
\text { expect }\end{array}$ & ounts less tl & & \\
\hline
\end{tabular}


The observed $\chi^{2}$ value of 7.5054 is statistically significant at the 0.0574 level. The null hypothesis is rejected and the hypothesis that there is a relationship between a race group and involvement in activities outside of the school environment must be deemed probable. The warning displayed of $25 \%$ of the cells having expected counts of less than five illustrates the small number of respondents in the Coloured and Indian ethnic groupings and they therefore are not disregarded, as they are integral to this study. The white racial group receives the most support in being involved in Arts and Culture activities outside of the school environment, whereas the other three racial groups indicate not being involved in Arts and Culture activities outside of the school environment. This does not imply a lack of commitment from the other three racial groups, but confirms the educator's level of expertise in the Arts and Culture learning area, where the white racial group displayed a tendency to having received specialised 'art' training as opposed to the other three racial groups. However, the lack of involvement can be seen as negative, since if an 'art' form is not practised it can result in diminishing capability.

\section{Conclusion}

It is evident from the data secured that the majority of educators do not have a specialisation in music or in any of the arts strands represented in the learning area Arts and Culture. With only $15 \%$ having any recognisable training in music, a vast majority of educators exhibit limited knowledge and this impacts on the delivery of Music in the learning area Arts and Culture through the inability of educators to provide extended opportunities for learners in curriculum and extramural activities. The apparent lack of involvement in the 'arts' outside of the school environment is also cause for concern as music education is viewed as systematic instruction in helping learners and educators alike toward becoming music teachers, composers and performers. Although the educators are qualified, they are not necessarily qualified in the 'arts' field and this manifests itself in educators performing activities for which they do not have a passion or interest.

It is noted that if the educator does not possess skills for the effective teaching and learning of music in their repertoire, then the learners will not be exposed to the development of such skills. Similarly, the art forms, and in particular music, cannot then take their rightful place in practice. The policy documents for C2005 acknowledge the worth of the arts, yet on the other hand the educators, or facilitators of input, are ill equipped in knowledge and skills to afford music its rightful and necessary place in the curriculum.

\section{Limitations}

This research interprets the context and practice of music in the learning area Arts and Culture in the Senior Phase (Grades 7-9) in the Gauteng province, and more specifically in two selected districts. The research work of the Music Action Team cells was not initiated or originated by me, but permission was granted by the PASMAE Executive for the findings to be interpreted for academic purposes. Such investigations are necessarily limited and omissions are inevitable. Because the main research was confined to the two districts in the Gauteng Department of Education, the analysis of the variables that are impacting 
on the delivery of music in the learning area Arts and Culture and the perceptions of educator, principal and learner attitudes cannot necessarily be applied to other provinces in South Africa. Since South Africa as a whole is undergoing dynamic curriculum change and development, this study suggests the need for continued research on a broader scale and an in-depth study of grassroots structures and mechanisms for the survival of music in the learning area Arts and Culture in the school curriculum.

\section{Recommendations}

Practising specialist music educators are highly necessary to ensure the survival, maintenance and full utilisation of music in the learning area Arts and Culture. A collective force needs to be structured by specialist music educators with a common vision of empowering non-specialist educators with the necessary skills and knowledge in music. No text book or document can replace the skills or knowledge that the individual has acquired and therefore these skills and knowledge need to be utilised as a necessary resource for the development of educators' skills and training.

Higher education institutions need to be approached and the findings of this research discussed. The institutions would need to design course material appropriate for developing skills and training for educators who have little time and limited financial resources. A major aim of pre-service education should be to assist in the preparation of autonomous and professional educators with high levels of appropriate knowledge and skills. This aim needs to be realised through collaborative forums between higher education institutions and the National Department of Education together with practising educators.

Both the National Department of Education and National Department of Arts and Culture should recognise that the further professional development of practising educators is crucial to the future of the arts and consequently they should provide the financial commitment for this to take place. Key service providers of the arts would then be able to tender for acknowledgement by the South African Qualifications Authority to be permitted to offer practical development courses for the advancement of practising art educators. A National Framework for partnerships with higher education institutions, non-government organisations and the private sector would create the space for exchange of services. This would create a structured and systematic in-service training programme for classroom educators, school management teams and departmental support personnel.

For music to achieve its full potential within the learning area Arts and Culture, it is essential for the National Department of Education and in turn the Provincial Departments of Education to recognise the value of music in the learning area Arts and Culture and to provide the necessary human and physical resources for its effective implementation. For instances where such resources are not available, it is necessary to take cognisance of this research and previous research in order to address the variables which are impacting on the delivery of Music in the learning area Arts and Culture.

The contributions of music in the context of education in the learning area Arts and Culture attempt to be meaningful and experiential. I believe that it is mandatory that such contributions should be made available to every learner. It is therefore imperative that human and physical resources be readily accessible and supported in view of the societal role of the arts. 


\section{References}

ASMAL, K. (2000) Address to the Music in schools Symposium. http://education.pwv.gov.za/Media/Speeches 2000/May/Music.htm> [Accessed 28 November 2000]

BREIDLID, A. (2003) 'Ideology, cultural values and education: The case of Curriculum 2005', Perspectives in Education, 21 (2), June, 83-101.

CHURCHMAN, C. W. (1968) The Systems Approach. New York: Dell.

FRIEDMAN, H. (2003) 'The poor cousin of the academic family', The Teacher, 8 (2), 4.

HAUPTFLEISCH, S. (1997) Transforming South African Music Education: a Systems View. Unpublished DMus thesis: University of Pretoria. http://www.gauteng.net/home/fact.asp Gauteng: Fact sheet. [Accessed 18 August 2003]

HERBST, A., DE WET, J. \& RIJSDIJK, S. (2005) 'A survey of Music Education in the Primary Schools of South Africa's Cape Peninsula', Journal of Research in Music Education, 53 (3), 260-83.

KHULISA MANAGEMENT SERVICES (2002) Evaluation of C2005 Implementation in Gauteng Province Challenges, Constraints, Innovations and Successes of 1998 to 2001. Johannesburg: GICD.

KLOPPER, C. J. (2003) Multi-disciplinary arts education: A South African perspective for Music within the learning area Arts and Culture and its applicability throughout Africa. Conference proceedings of the 29th International Conference for the Southern African Society for Education. University of North-West.

KLOPPER, C. J. (2004) 'Variables impacting on the delivery of Music in the learning area Arts and Culture in South Africa', Unpublished D Mus thesis. http://upetd.up.ac.za/thesis/available/etd-08222005-140312 [Accessed 18 June 2007]

KLOPPER, C. J. (2005) 'World sounds through universal fellowship: linking African sounds through collaborative networking', International Journal of Music Education, 23, 153-8.

OPPENHEIM, A. N. (1992) Questionnaire Design, Interviewing and Attitude Measurement. London: Continuum.

OSSENBRUGGEN, P. J. (1994) Fundamental Principles of Systems Analysis and Decision-making. New York: John Wiley.

RIJSDIJK, A. S. C. (2003) 'An investigation into the state of music education in the learning area arts and culture in primary schools of the Western Cape Metropole', Unpublished MMus dissertation, University of Cape Town.

SOUTH AFRICA (1994) RDP office. White paper on the Reconstruction and Development Programme. http://www.info.gov.za/gazette/whitepaper/1994/16085.pdf (Accessed 18 June 2007)

SOUTH AFRICA (1995a) Education and Training in a Democratic South Africa: First Steps to Develop a New System. Government Gazette, 16312, 15 March 1995.

SOUTH AFRICA (1995b) School Education Act (GAUTENG) [Act 6 of 1995]. http://www.education.gpg. gov.za/Archives/Documents/MEMORANDUM\%20THE\%SCHOOL\%20EDUCATION\%20BILL, \%201995.htm (Accessed 18 June 2007).

SOUTH AFRICA (1995c) South African Qualifications Authority Act. http://www.info.gov.za/acts/1995/a5895.pdf (Accessed 18 June 2007)

SOUTH AFRICA (1995d) White paper on Education and training. Government Gazette No. 16312. http://www.info.gov.za/whitepapers/1995/education1.htm (Accessed 18 June 2007)

SOUTH AFRICA (1996a) Lifelong Learning through a National Qualifications Framework. Pretoria: Department of Education.

SOUTH AFRICA (1996b) National Education Policy Act 27 of 1996. http://www.education.gpg. gov.za/Archives/Documents/National\%20Education\%20Policy\%20Act\%2027\%20of\%201996.htm (Accessed 18 June 2007)

SOUTH AFRICA (1996c) South African Schools Act 84 of 1996. http://www.education.gpg.gov.za/Archives/ Documents/Gauteng\%20Schools\%20Act\%206\%20of\%201995.htm (Accessed 18 June 2007) 
SOUTH AFRICA (1996d) The Constitution of the Republic of South Africa Act 108 of 1996. http://www.info. gov.za/documents/constitution /index.htm (Accessed 18 June 2007)

SOUTH AFRICA (1997a) Curriculum 2005. Pretoria: Department of Education.

SOUTH AFRICA (1997b) Policy Document: Senior Phase (Grades 7 to 9). http://www.education.gpg.gov.za/ Curriculum/RNCS\%20for\%20Senior\%20Phase.pdf (Accessed 18 June 2007)

SOUTH AFRICA (2000) Arts and Culture. Illustrative Programme C2005. Senior Phase Grade 8. Pretoria: Department of Education.

SOUTH AFRICA (2002a) Government Gazette No 23406. Government Notice 710. 31 May 2002. Pretoria: Government Printers.

SOUTH AFRICA (2002b) Revised National Curriculum Statement Grades R-9 (schools) Policy Overview. http://www.education.gpg.gov.za/Curriculum/Policy.htm (Accessed 18 June 2007).

TAYLOR, N. (1997) Curriculum 2005: some issues. Joint Education Trust Bulletin. October 7: 1-3.

VAKALISA, C. G. (2000) Inaugural lecture: Curriculum, teachers and teaching: Where does the answer for educational reform lie? Educare, 29 (1), 13-27.

VICTORIA. Ministry of Education. (1998) The Arts Framework. Melbourne: Publishing Services. 